\title{
Discussion about the Development of public English teachers turned into the teachers of English for Specific Purpose
}

\author{
Gao Shuangxi \\ College of Mechanical and Electrical Engineering \\ Huanggang Normal University \\ Huanggang, Hubei Province, China \\ Shuangxigao@qq.com
}

\author{
Zhao Hailing \\ School of Foreign studies \\ Huanggang Normal University \\ Huanggang, Hubei Province, China \\ hailingzhao@qq.com
}

\begin{abstract}
In recent years, the English teaching of High vocational colleges in our country hasn't adapted and satisfied to the needs of the social circumstances and development. However, English for Specific Purpose is playing an increasingly important role .the Author analyzed rationality to the two aspects in teaching condition of English teachers and the organization of the faculty, to propose the way of high vocational public English teachers turned into the teachers of specialized English.
\end{abstract}

Keywords-English for Specific Purpose; development; cooperation

\section{INTRODUCTION}

With the accelerating of technology and social economy,the competition is increasingly fierce. China needs a large number of both possessed professional knowledge and professional communication in English compound interdisciplinary talents.

From the initiative to meet the needs of social and economic development, higher vocational education is the employment education. The vocational public English curriculum is gradually inclined towards to English for Specific Purpose curriculum. The professional English teaching has become more and more reflects its role and position, and pure English language teaching has been unable to meet the requirements of non English Majors in Vocational colleges[1].

Expert Tang Xiao Ye proposed in 2007, to promote the combination of English and industry major, the professional industry English will be an effective way to improve English Teaching in Higher Vocational colleges. Professional industry English also called English for Specific Purpose ESP. It is a bridge between Basic English and professional English, which is characterized by the combination of students' practice and the requirements of foreign language skills in the future and strengthen the employment guidance and ability standard[2]. In this paper, the emergence of the "professional industry English teachers" refers to a person who teaches a professional English curriculum in vocational colleges, such as mechanical English teacher, electrical English teachers and computer English teachers, etc...

\section{THE TEACHING PRESENT SITUATION IN CURRENT PUBLIC ENGLISH AND THE GROUP SITUATION OF PROFESSIONAL INDUSTRY ENGLISH TEACHERS}

At present, the students of higher vocational colleges are uneven, the students' English foundation is poor, and most of them are from countryside. Students in English listening, speaking and other aspects of the overall quality are generally not high. The blind enrollment result in admission too many students study in college which is not qualified in English level.

\section{A. The group of teaching staff in public English and the current situation in English teaching}

Public English teachers, which means most teachers graduated from English major, they are study in college of English literature, English pedagogy, foreign language teaching theory and Foreign English cultural studies program, etc.

There are serious problems in the construction of English Curriculum in higher vocational colleges. Such as lack of vocational characteristic, have not enough professional ability. On the one hand, it has not been formed the employment oriented consciousness, the curriculum system and the content of the curriculum system are very old, It lacks the characteristics of modern education and targeted $\mathrm{m}$ easures.

Characteristics which caused the students have not useful at works in the future and influenced their enthusiasm of English studies. On the other hand, due to the obstacles for traditional curriculum, the purpose of English teaching is to pass the examination of province in "Higher Vocational Practical English rank test (A / B)", which little considered the actual demand of the higher vocational education, the learning motivation and initiative of students is weariness and have no passion to studies. 


\section{B. The group of professional English teaching staff and the current of teaching situation}

As the requirements of occupation and employment, many vocational college students are reluctantly accept ESP curriculum. The resource of ESP teachers are scare and has their limited, for example, lack of teachers, knowledge structure and teaching method are simple. Not high level in English teaching. The overall quality of teachers is not ideal, cannot meet the needs of industry professional English teaching. Some of the professional English courses are teaching by professional teachers which not graduated from English major. They also meet the same question, such as be familiar with the professional English vocabulary, have strong ability in English reading, but listening is weakness. The teachers who teaches public English can use it natural .Unlike non English major, they are lack of grammar knowledge, not understanding the English teaching, the process generally : teach students to read the new professional English words, then turned to explain the content of specialized knowledge or study ESP courses just to translate the course. There is no doubted contrary the original intention of the professional English teaching. On the other hand, public English teacher turn to teach ESP ,They are limited by his major or his experience. Most of them have no working experience in the company and have no professional background of ESP. Lacking of the practice knowledge and industry knowledge which related .Therefore, in the teaching activities, this part of the teacher in the industry professional English teaching, especially the science and engineering teaching content, easy to produce blue mood in resistance and frustration.

The new situation of vocational education is professional, openness, application and technicality .They requires of professional English teachers. It demands the teacher not only understand how to use language, but also understand the professional; both can teaching in theoretical, and has a certain practical ability. The group of teachers in higher vocational college to achieve the above mentioned has a certain distance. But professional industry teachers or the College English teachers, the teachers' team level is uneven, teaching method and process is single. Students have no good method to learn. They have no passion to study. Thus, it cannot be very good to meet the requirements of professional personnel training.

In order to adapt the reformation and to improve the students practical English, the author considers that the public English Teaching in higher vocational colleges is required to serve the English for Specific Purpose, and gradually abolish the public English courses, for strengthen the construction of the practical English and English for Specific Purpose. The construction of teaching staff is no time to delay in courses construction and team building.

\section{THE DEVELOPMENT DIRECTION OF THE PROFESSIONAL INDUSTRY ENGLISH TEACHERS IN HIGHER VOCATIONAL COLLEGES}

From the teacher's resources, learning environment to combination practical English and professional industry English teachers, we can reduce the time; enhance the effect, for the professional post and academic ability. Public English teaching turn to the industry professional English is inevitable, in this new situation, only in the rapid and effective way to develop a professional English teaching, it can better meet the needs of Higher Vocational English education[3].

The industry professional English teaching demands the English teacher have high requirements: firstly, the professional industry English teachers must have a solid foundation of theoretical industry, which comprehensive the industry knowledge and experience; it also can understand the latest developments of the industry, and have a deeper research in his field. Secondly, the industry professional English teachers must have a high level of English, that is to say, the English teacher have the ability to skillfully use English to explain industry knowledge, and competent bilingual teaching. Thirdly, the professional industry English teachers need to have the modern teaching ideas; it can train the students' creative consciousness, increase creativity and other appropriate professional skills. Fourthly, the professional industry English teachers should also have the spirit of hard work, must be regularly to the enterprise, industry practice, and have the experience of working environment for graduates, it also understand the latest needs of the employing units.

\section{THE DEVELOPMENT APPROACH TO PUBLIC ENGLISH} TEACHERS TURNS TO THE PROFESSIONAL INDUSTRY TEACHERS

According to famous linguist Crandall dissertation, developing of teachers is a lifelong process, which includes the study of collective or individual autonomy. Teachers' development only decides by themselves, and for their needs to research[4].

\section{A. Cultivate interest and find the right position}

Higher vocational public English teachers should be in accordance with the requirements of professional and industry development, adjust the mentality, look back on the past whether they have the enterprises to visit, sensory experience and relevant professional knowledge reserves, according to the usual understanding and communicating with teachers in professional and training places, finding their professional interest, to locate for themselves, and be engaged in the professional English direction, design and adjust the development goal, to seek for their own development ways, and to promote in teaching experience, teaching attitude, professional qualities and teaching skills in practice and reflection.

\section{B. Continuous learning, self-reflection and positively enterprising}

The most direct and effective way to improve the professional industry English teachers in higher vocational colleges is to reflect on. Reflection is the process of the teachers taking their own teaching activities as the object of thinking, and also is the process of examining and analyzing on their own behavior, decision-making and the results of making. It is a way which improve participate ability of self awareness level to promote the development. 
1) Studies by themselves is the need for the development of teachers, but also is the basic for understanding the industry knowledge

Teachers study by themselves have their own advantages, we can through the following ways:

Use of the school library and professional teaching conference, through professional data self -learning, and we have the advantage of teaching resources to open mind ask question with relevant teachers. Also we can use of spare time with the basic courses of freshman studies for the breakthrough, listening to the professional teachers with plans and exchanging each other when they meet some questions.

2) Learning professional network knowledge, is the dual needs of vision and understanding

Public English teachers in higher vocational colleges can use the rich network resources to find the necessary information for the industry professional in the development of teaching when they are trend to process of professional industry teachers. Teachers not only search and industry related pictures by a powerful search engine tools, such as Badu, Google, searching some valuable pictures, audio and text data. At the same time, it can from the CNKI, VIP information website to search the related literature, expand knowledge, to enrich them, improve the quality of higher education teaching.

\section{Attending training, strengthen practice and hard skills}

Higher vocational colleges is to cultivate "high quality skilled professional personnel", its education is characterized by "practical application for the purpose", therefore, the industry professional English teaching should be combined with special characteristics, The professional industry English teachers should understand the industry knowledge to enhance their ability ,practice more and constantly improve themselves

1) Attending training actively and strengthen understanding of the relevant industry

Training is an important way to promote the development of professional English teachers in the industry. Public English teachers should be trained in two aspects, including language and professional when they are decided to trend. Specifically, it includes improving the English language skills and mastering the knowledge structure, teaching methods and the characteristics of the English language. The form of training includes lectures, scientific research, visiting, learning online, short-term training, cooperative research, etc..

2) Strengthen the professional foundation of practical operation and enhance the understanding of the professional

In the process of Public English teachers transformed to professional industry English teachers, not only to have a certain understanding of his major and application but also have understanding on the basic professional, it should also have some grasp of the professional knowledge, especially knowledge practice, compared with students, teachers in the use of time and resources has more advantages, and should make full use of school experiment and training. School in mill and research conditions, Worship Training Guide teacher, device identification and basic training for the experiment operation, enhance understanding of professional skills.

3) Use the part-time learning studying related industry knowledge and be familiar with the industry culture

Teachers can do part-time jobs in the weekend or summer vocation, be familiar with the industry culture, understand the connotation of the culture industry, also can use school enterprise cooperation unit resources or actively participate in field work, enterprises to visit or hangs duty to take exercise, understand the business, practice more in enterprise. This will helpful for teachers to combination with the original pure language teaching and single skill training, try to import the industry culture in English teaching, For better mobilize the enthusiasm of the students, we can cultivate their communicative competence and the ability of industry to adapt to the overall situation awareness and deepened the understanding of their own culture, enhancing the students' ability to adapt to the market and competitiveness. In addition, it can guide and regulate the students' thinking and behavior, so that students feel industry (or professional) culture, gradually understand agreement and consciously comply with the quality requirements of the relevant industry, the formation of a good professional quality. it is a bridge for higher vocational students completed the transfer of professional knowledge, to prepare students for a successful career.

\section{CONSTRUCTIONS THE INDUSTRY ENGLISH}

PROFESSIONAL COURSES AND COOPERATIVE TEACHING FOR PROMOTE THE CONSTRUCTION OF TEACHERS

Mutually beneficial and harmonious cooperation can promote the development of themselves .In the process of Public English teacher's trend to the professional industry English teachers. through the industry professional English course construction to promote the industry professional English teachers team construction, Combined with the good effect of professional English teaching method,This model is the most effective professional in English teaching .it is not only created a good atmosphere of both competition and cooperation.

The public English teacher and the industry professional English teacher should study each other. They can determine the teaching plan, preparation of teaching materials, focus on preparing lessons together, and take the teaching task of industry English, in the long-term cooperation in the exploration. They can summary to adapt to effective learning programs. Professional teachers act as consultants when they need to help the industry professional English teachers to solve some of the problems of professional knowledge. Mutual give lectures in competitions, of course, can also be bilingual teaching, learning from each other, mutual learning, mutual evaluation, common improvement.

In addition, the professional English teachers in higher vocational colleges should often communicate with other colleges for exchange the teaching experience. They can often reading publications and take an active part in academic conference. 
In the case of limited outside communication, we should be good at making full use of the opportunity of cooperation between the school and other schools communication. Thus, in class teaching, English skills and a certain professional knowledge can be organically combined in the class, and gradually form a better practical ability of English teacher and a deeper English skills which has a deeper English skills and strong professional foundation.

\section{SUMMARY}

Setting up the Professional English course in industry is provide a broad space for the development of professional English teachers, and to developed of professional English teachers, also good for the development of the professional industry English to provide a strong support for the development of the industry, the two are complementary.

The teachers' quality is the main factor which affects the quality of professional English teaching, and the Public English teacher trends to professional industry English teachers developing is a lifelong process. Teachers should study and update their knowledge, sometimes can read some books and magazine with related. To improve their teaching and practice level, constantly explore practical English how to combined with the professional English, renew their ideas, strengthen their learning and reconstruct teaching contents, They can use a new teaching methods and means, so that students can make their own assessment of high quality skilled personnel.

At the same time, the vocational colleges should improve the professional English teachers' training and learning motivation and evaluation mechanism, formulate preferential policies, provide favorable conditions which improve the professional quality of English teachers in teaching level, and satisfaction of vocational education demands.

\section{REFERENCES}

[1] Dai Mingzhong,ESP and the College English teaching [J],Journal of Chengdu University (SOCIAL SCIENCE EDITION), 200902

[2] Zhouyi,College English major for ESP teaching situation investigation and strategy research [D],Shanghai International Studies University in 2009

[3] Zheng Yuanyuan,cooperative teaching mode in the teaching of specialized English [D],Chongqing University in 2008

[4] Li Rui,the status quo of ESP teaching in higher vocational colleges [D], Dalian Maritime University, 2009 